\title{
INFLUENCE OF PARENTS AND PEER-GROUP ON CHOICE OF BUSINESS EDUCATION PROGRAMME AMONG SECONDARY SCHOOL STUDENTS IN ZARIA METROPOLIS, KADUNA STATE
}

\author{
Dr. ADAMU IBRAHIM
}

LILLIAN B. MARCUS

Dept. of Vocational and Technical Education, Ahmadu Bello University, Zaria, Nigeria

\begin{abstract}
This study investigated the Influence of parents and peer group on choice of business education programme among secondary school students in Zaria metropolis, Kaduna state. The study had four objectives. Four research questions were raised to guide the study while two null hypotheses were formulated and tested. Descriptive survey research design was used for the study. The population of the study was 8865 SS III students that registered for UTME in Zaria metropolis. Three hundred and eighty two students were used as sample for the study. The instrument used to collect information from the respondents was self- structured questionnaire, titled Students Choice of Business Education (SCBE). Data were collected by researcher assisted by seven (7) research assistants using face to face method. Data collected were analyzed using mean score for answering the research questions and Pearson Product Moment Correlation for testing the two null hypotheses. The study revealed among others that parents have influence on the choice of business education programme among secondary school students in Zaria metropolis. It was concluded that in a short run lesser number of students would be offering Business subjects in senior secondary schools level because most parents and peer group discourages students from opting for educational related course. The research recommended among others that secondary schools authority in Kaduna state should invite parents to create awareness to them on career day. This will enable parents to appreciate the importance of Business subjects
\end{abstract}

Keywords: $\quad$ Parents, Peer-group, Choice, Business Education

\section{Introduction}

Secondary school is the final transitional stage to students planning to progress to tertiary institutions in Nigeria. The level prepare students to have strong educational background before proceeding to higher education (University, polytechnic, or college of education), with the simple focus of subject tracking for the purpose of having and producing experts or specialists in subject area. Immediately after high school graduation, students are both overwhelmed and excited with the thought of striking out on their own and starting to work towards their own career aspirations. These newly graduated students are the ones making the decisions for their futures now, and with fresh eyes, they are thrust into this whole new world. Most students have limited thoughts as to where to begin, so they start by choosing to attend college or some form of higher education. The decision of which school to attend encompasses its own set of reasons, but what is it that makes these students so sure of the particular career path that they choose. Students graduating from secondary schools in Nigeria that are willing to further their studies at higher institutions have to undergo a standard examination called the Unified Tertiary Matriculation Examination (UTME) conducted by Admissions and Matriculation Board (JAMB). The examination boarding is responsible for conducting the examinations and forward the scores of successful candidates to the choose universities. The decisions for the choice of careers among UTME candidates are problematic decisions that students face while completing their secondary education. 
Business education is one of the vocational and technical education programme in tertiary institutions in Nigeria. The programme admit students and prepare them to achieve business skills with personal economic competence and to provide courses and experiences which will equip students with the foundational knowledge about business enterprise, personal economics, money and banking, law, etc. while at the same time, strengthening their basic reading, writing, mathematical, and interpersonal skills needed for teaching profession. The philosophy of the programme according to National Policy on Education (2014) among others is to:- (i) prepare students with basic business skills which will enable them to succeed in business curriculum courses in college; (ii) graduate students who are able to interpret economic issues which effect them and to manage their economic affairs efficiently and wisely; (iii) create and expand new and updated course offerings so that our business curriculum will be flexible and sensitive to change and reflect the needs of our students; and (vii) provide an atmosphere of learning and example that will encourage each student to learn and to perform to the students' fullest potential.

The role of parents in upbringing and training of their children cannot be overemphasized. The link between parents and children has significant influence on their career decision. Report of GTI Media (2017) revealed that parents play a significant role on decision-making of career decision of their children. Generally would wish their children to achieve where they failed to achieve. To enable them achieve this, they ensure that they send their children to high-class school of their desired. In their research, Tziner, Loberman, Dekel and Sharoni (2012) found that the better the parent-child relationship is, and the more support the child felt, the more willing the child was to take career choice advice from the parent. If this positive parenting impacts children's career choices.

Peer groups are an important influence throughout one's life, but they are more critical during their developmental years of adolescence. There is often a controversy about the influence of a peer group versus parental influence, particularly during adolescence. The power of the peer group becomes more important when the family relationships are not close or supportive. If the parents are largely unavailable, the children may turn to their peer group for emotional support. Most children in this situation are not discriminatory about the kind of group they join. They would often turn to a group that accepts them, even if the group is involved in illegal or negative activities. For some young people, the need for affiliation or closeness is often greater than the need to "do the right thing" (Alika, 2010). The adolescents today are socialized more within the confines of their peers than with adults, it is therefore necessary to give student guidance and counseling services. The citations prompted the researcher to investigate the parents and peer-groups influence on choice of business education programme among secondary school students in Zaria metropolis, Kaduna state

\section{Statement of the Problem}

Secondary school students are faced with the problem of deciding on future career paths upon graduation. Career decision is very fundamental on future and aspiration of secondary school students. In spite of the versatility of vocational and technical education options available for students to select, many young people and their families see business education as a setback sector or option in their quest for 
economic improvement, even though these disciplines are still relevant in the present economic structure (Evoh, 2012). According to Adamu (2011), many parents considered business education is meant for academic and social misfits, problematic and lawless elements, so peer groups and counsellors tend to support this retrogressive view. Report by Diji et al, (2015) revealed that in 2001 out of 4,032,083 students that sat for JAMB, only 1835 opt for vocational and technical education.

It is obvious that Business Education is usually not the first choice of study, and most students that secured admission in the area struggle for change of course as students view the profession with the mindset that it is education meant for the less privilege or a programme which upon graduation there is simply no opportunity for securing a job (Ohiwerei 2009). This is a great and worrisome phenomenon facing general students but still, less is known in business education which this research study seeks to make an explorative study on factors influence choice of business education among secondary school students in Zaria metropolis, Kaduna state.

\section{Objectives of the study}

The study wish to:

ascertain the influence of parents on choice of business education programme among secondary school students in Zaria metropolis, Kaduna state

determine the influence of peer group on choice of business education programme among secondary school students in Zaria metropolis, Kaduna state

\section{Research Questions}

The following research questions were raised:

What is the influence of parents on choice of business education programme among secondary school students in Zaria metropolis, Kaduna state?

What is the influence of peer group on choice of business education programme among secondary school students in Zaria metropolis, Kaduna state?

\section{Research Hypotheses}

The following research questions were raised

There is no significant influence of parents on choice of business education programme among secondary school students in Zaria metropolis, Kaduna state There is no significant influence of peer group on choice of business education programme among secondary school students in Zaria metropolis, Kaduna state?

\section{Methodology}

\section{Research Design}

The study adopted descriptive survey design. The design is concerned with the collection of data for the purpose of describing and interpreting existing conditions, prevailing practice, beliefs, attitudes and ongoing process. Survey involves a detail 
and critical examination of effects of parental and peer-group influence on students' choice of Business education. According to Usaula (2005) survey research design is very useful in answering research question, adding that it is very important to gather information from a target population numbering some hundreds or thousands.

\section{Population and Sample for the Study}

The population of this study comprised of 8865 SS III students that registered for UTME in Zaria metropolis. Krejice and Morgan's (1970) recommended a sample size of 379 for the study. In order to enable the researcher get reasonable representation for the study, the sample size was increased to 382. This decision was based on suggestion of Douglass (2006), who opined that sample size has to be big enough to enable a researcher to detect the smallest worthwhile effect or relationship between variables. Proportional sampling technique was used to select the 6 schools and number of students that represented the metropolis.

The researcher used simple random technique of YES or NO to select the respondents. In this regard, those who picked YES constituted the sample of the study. For the purpose of this study simple random sampling using 'Hat' drawn method was adopted in the selection of the sample size.

\section{Instruments for Data Collection}

The instrument used to collect information from the respondents was self- structured questionnaire, titled Students Choice of Business Education (SCBE). The instrument has sections A and B. Section A elicits bio-data information of gender from the respondents. The questionnaire was constructed in a four (4) rating scale of Strongly Agree 4 points, Agree 3 points, Disagree 2 points and Strongly Disagree 1 point.

To ensure that the instrument meets the expected standard of validity, consultations were made with Business education in Ahmadu Bello University, Zaria. The experts examined the test items for its appropriateness, clarity of statement whether or not the test items were well structured, suggestions and criticisms made to improve the test quality of test items were incorporated into the final copy of the questionnaire. After vetting the instrument, their corrections and suggestions were incorporated in the final copy. According to Uzosike (2008), face validity of a survey instrument of this nature was considered adequate. The instrument was therefore considered suitable for the study.

\section{Pilot Study}

A pilot study of the instrument was conducted with 30 secondary school students in Kaduna state, which is not the study area. The pilot study was carried in different study area. The choice of the area for the pilot study was based on the similarity of the characteristics with the study area. The respondents were given the questionnaire to complete. The pilot study was conducted to obtain the reliability of the instrument. Reliability coefficient of 0.82 reliability was obtained. According to Olayiwole (2010) a reliability estimate of 0.60 and above is considered high and therefore the instrument was considered reliable for the study, 


\section{Procedure for Data Collection}

Face to face method was used for data collection assisted by seven (7) research assistants covering each school in the study area. Before the administration of the questionnaire, interaction was held with the respondents used to create rapport.

\section{Procedure for Data Analysis}

The data collected through questionnaire from the respondents through the research assistants was analyzed. The section A of the questionnaire was analyzed using descriptive statistic of frequency and percentage. Other responses was based on four (4) point rating scale, a mid-point mean of 2.5 was used as positive response criterion mean and accepted as positive response because the average of individual mean score was 2.5 i.e. $\{(4+3+2+1 \div 4)=2.5\}$. Thus any mean score range from 2.5 and above was regarded as positive and accepted. While any score below 2.5 was for disagree. Pearson Product Moment Correlation was used to test the two null hypotheses at 0.05 level of significance.

\section{Result of the study}

The results of data used to answer the research questions are presented in Table 1 to 4 .

\section{Research Question One}

What is the influence of parents on choice of business education programme among secondary school students in Zaria metropolis, Kaduna state?

Table 1: Descriptive statistics used to answer research question one

Total

Responses Agree Disagree

Mean Score Std. Dev. Remark Decision

\begin{tabular}{lllllll}
\hline 6461 & 4041 & 2420 & 3.13 & 1.59 & $3.13>2.50$ & $\begin{array}{l}\text { Positive } \\
\text { influence }\end{array}$ \\
\hline \hline
\end{tabular}

The analysis of data used to determine research question one revealed the cumulative score of 6461. Students who opined that parental influence determined their choice of business education scored 4041 with the mean score of 3.13. Those with contrary views scored 2420 with standard deviation of 1.59 . From the analysis, the mean score obtained shows that parents have influence on choice of business education among their children.

\section{Research Question Two}

What is the influence of peer group on choice of business education programme among secondary school students in Zaria metropolis, Kaduna state? 
Influence of Parents and Peer-Group on Choice of Business Education Programme among Secondary School Students in Zaria Metropolis, Kaduna State

Table 2: $\quad$ Descriptive statistics used to answer research question two

Total

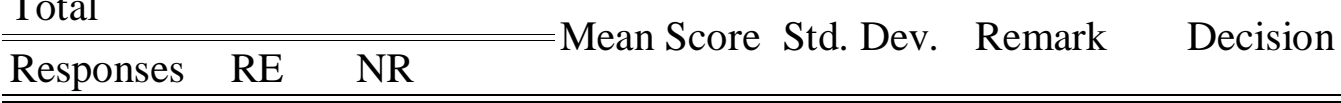

\begin{tabular}{lllllll}
\hline 6309 & 3875 & 2434 & 3.07 & 1.60 & $3.07>2.50$ & $\begin{array}{l}\text { Positive } \\
\text { influence }\end{array}$ \\
\hline \hline
\end{tabular}

The analysis of data used to determine research question one revealed the cumulative score of 6309. Students who opined that peer groups have influence on choice of business education scored 3875 with the mean score of 3.07. Those with contrary views scored 2434with standard deviation of 1.60. From the analysis, the mean score obtained shows that peer group have influence on choice of business education of secondary school students.

\section{Test of hypotheses}

The results of test of hypotheses are presented in Table 5 and 6.

Ho1: There is no significant influence of parents of choice of business education programme among secondary school students in Zaria metropolis, Kaduna state

Table 3: $\quad$ PPMC on influence of parents of choice of business education programme among secondary school students in Zaria metropolis, Kaduna state

\begin{tabular}{lllllll}
\hline Variables & Mean & Std. Dev & N & r-cal & r-crit & p-value \\
\hline Parental influence & 3.13 & 1.59 & 317 & 0.198 & 0.195 & .002 \\
Choice of business education & 2.58 & 1.59 & 317 & & & \\
\hline
\end{tabular}

The result of PPMC used to test null hypothesis one revealed the mean scores of 3.13 and 2.58 for Parental influence and Choice of business education with standard deviations of 1.59 and 1.34 respectively. From the analysis, the r-cal value was found to be greater than $r$-crit $(0.198>0.195)$. The p-value of .002 obtained was less than 0.05 level of significance. The result therefore shows that significant influence exists between the two variables. The null hypothesis was not retained.

Ho2: There is no significant influence of peer group on choice of business education programme among secondary school students in Zaria metropolis, Kaduna state?

Table 4: $\quad$ PPMC on influence of parents of choice of business education programme among secondary school students in Zaria metropolis, Kaduna state

\begin{tabular}{lllllll}
\hline Variables & Mean & Std. Dev & N & r-cal & r-crit & p-value \\
\hline Pear group influence & 3.07 & 1.06 & 317 & 0.211 & 0.195 & \multirow{2}{*}{000} \\
Choice of business education & 2.58 & 1.59 & 317 & & & \\
\hline
\end{tabular}

The result of PPMC used to test null hypothesis one revealed the mean scores of 3.07 and 2.58 for Peer group influence and Choice of business education with standard 
deviations of 1.06 and 1.59 respectively. From the analysis, the r-cal value was found to be greater than $r$-crit $(0.198>0.195)$. The p-value of .000 obtained was less than 0.05 level of significance. The result therefore shows that significant influence exists between the two variables. The null hypothesis was not retained.

\section{Discussion of the findings}

The finding of research questions one which was supported by test of corresponding null hypothesis shows that parents have influence on the choice of business education programme among secondary school students in Zaria metropolis. The finding is in agreement with Okeke (2000) who reported that parents had a significant effect on students' choice of career and subjects. Parents' characteristics played a vital role in students' choice of technical subjects. Similar, Mabunda (2002) reported that parents had a crucial task of preparing the child for education. In their task of socializing the child's parents had a greater influence on the child's development and future life choices.

Analysis of data shows that peer group has influence on the choice of business education programme among secondary school students in Zaria metropolis. The was in agreement with that of Jones and Larke (2001) and Robertson and Symons (2003) who reported peer groups have influence on career choice of youths in schools. Similarly, Adnett \& Turnbull (2003) observed that student's choice of subject may be influenced by the aspirations of their peer group or through the expectations that schools had for that peer group. School managers believed that certain subjects were more appropriate for the type of pupils that attended their school.

\section{Conclusions}

The results of study show that parents and peer group have significant influence on choice of business education programme among secondary school students in Zaria metropolis. Based on this, it was concluded that at short run lesser number of students would be offering Business subjects in senior secondary schools level because most parents and peer group discourages students from opting for educational related course.

\section{Recommendations}

Based on the outcome of the study, the following recommendations were made.

School authority should invite parents to create awareness to them on career day. This will enable parents to appreciate the importance of Business subjects and stop discouraging their children from offering subjects in secondary schools.

To encourage students on choice of Business subjects, schools should strengthen the guidance and counselling services to encourage career exploration and informed decisions by students. Proper guidance and counseling service would help restrain teachers' influence that might discourage students from choice of Business subject 
References

Adamu, I. (2011). The Need for the Introducing of Computer Technology to Curriculum of Business Education Programme in Tertiary Institutions in Nigeria. Ahmadu Bello University Journal of Vocational Studies, 5 (1): 1-4. A Publication of the Department of Vocational and Technical Education Ahmadu Bello University Zaria.

Adnett, N., \& Davies, P. (2003). Schooling reforms in England: From quasi-markets to competition? Journal of Education Polic, 18 (4): 393-406.

Diji, C. J.; Adeniji, J. A. \& Anam, B. (2015). Technical and Vocational Education and Training (TVET) and the Challenges of Youth Unemployment in Nigeria. International

Donald Robertson \& James Symons, 2003. "Self-selection in the state school system," Education Economics, Taylor \& Francis Journals, 11 (3): 259-272.

Douglas, K. A. (2006). Women's stories of parental influence in the career development process of becoming veterinarians. Guidance \& Counseling,

Evoh, C. J. (2012). Taming the Youth Bulge in Africa: Rethinking the World Bank's Policy on Technical and Vocational Education for Disadvantaged Youth in the Knowledge Economy. Education Strategy in the Developing World: Revising the World Bank's Education Policy, 337-369. doi:10.1108/S14793679(2012)0000016019

Federal Rep. of Nigeria (2014). National Policy on Education Lagos: Federal Ministry of Education.

GTI Media (2017). From education to employment: experts in early careers. From http://groupgti.com/

Jones, W. A. and Larke, A,. (2001). Factors Influencing Career Choice of African American And Hispanic Graduates of A Land-Grant College Of Agriculture. Journal of Agricultural Education, 42 (1).

Krejcie, R. V. \& Morgan, D. W. (1970). Determining Sample Size For Research Activities. Educational and Psychological Measurement, 30: 607-610.

Mabunda, N. P. (2002). The role of the school in preparing school leavers for selfemployment. Unpublished Doctorial Dissertation . University of south Africa. South Africa.

Ohiwerei, F. O. and Nwosu, B. O (2009): Vocational Choices among Secondary School Students: Issues and Strategies in Nigeria. Asian Journal of Business Management, 1(1): 1-5.

Okeke, A. N. (2000). The impact of school subjects on the choice of careers and profession. West African Journal of Education, 17 (1): 5 - 11. 
Olayiwola M. O. (2010). A Computational Method for the Solution of Nonlinear Burgers' Equation Arising in Longitudinal Dispersion Phenomena in Fluid Flow through Porous Media. British Journal of Mathematics \& Computer Science, 14 (5): 1-7, 2016.

Tziner, A.; Loberman, G. Z. and Sharoni, G. (2012). The Influence of the Parent Offspring Relationship on Young People's Career Preferences. Revista de Psicologia del Trabajo y de Las Organizaciones, 28 (2): 99-105. 7p. 5

Uzosike E. (2008). Validity and Reliability of Instrument. Unpublished paper presentation. 